\title{
Comparison of different antibody-conjugate derivatives for the development of a sensitive and specific progesterone assay
}

\author{
G. Hatzidakis, A. Stefanakis and E. Krambovitis \\ Department of Immunology and Diagnostics, Institute of Molecular Biology and Biotechnology, \\ Crete 71110, Greece
}

\begin{abstract}
Antibodies raised against progesterone with hormone-carrier protein bridges placed at four different carbon positions were used to compare the sensitivity and specificity of homologous and heterologous enzyme-hormone conjugates. All heterologous assays were at least twice as sensitive as the corresponding homologous assays. The best results were obtained by using antibodies against $7 \alpha$-carboxyethyl-thioether-progesterone with $6 \beta$ hemisuccinate-progesterone conjugate (or hemimaleate). The sensitivity with human sera was $0.25 \mathrm{ng} \mathrm{ml}^{-1}$ and, the highest crossreaction $10 \%$ with $5 \beta$-pregnane-3,20-dione, and reproducibility, recovery and accuracy were satisfactory. The correlation coefficient with radioimmunoassay in 103 human sera tested was $r=0.915$. The assay was successfully applied for the diagnosis of pregnancy in dairy cattle.
\end{abstract}

\section{Introduction}

Early methods for measuring progesterone concentration in the plasma or milk used radioimmunoassay (RIA) techniques (Robertson and Sarda, 1971; Heap et al., 1973; Hoffmann and Hamburger, 1973). Enzymeimmunoassays (EIA) are advantageous compared with RIA once problems inherent to EIA could be solved. Homologous EIA systems developed originally using $11 \alpha$-hydroxyprogesterone 11-hemisuccinate-base (Joyce et al., 1977; Sauer et al., 1981; Munro and Stabenfeldt, 1984) were unsatisfactory. Considerable improvements in sensitivity and specificity were reported with heterologous systems using antibodies to the above antigen in combination with conjugates $11 \alpha$-hydroxyprogesterone 11-glucuronide (Sauer et al., 1986) or progesterone-3-O-carboxymethyl oxime (Munro and Stabenfeldt, 1984; Marcus and Hackett, 1986), and antibodies to progesterone$7 \alpha$-carboxyethylthioether with $6 \beta$-hydroxyprogesterone-6hemisuccinate as conjugate (van de Wiel and Koops, 1986). The above assays evaluated only one antibody-conjugate system without a clear indication of which system was preferable. In the study reported here, polyclonal antibodies were produced to all of the above-mentioned progesterone-BSA antigens and were used to compare combinations of homologous and heterologous EIA systems for measuring progesterone. An assay was developed based on the best antibody-conjugate combination and its characteristics were assessed.

\section{Materials and Methods}

\section{Reagents}

All steroids used in the study were purchased from Steraloids (Wilton), unless otherwise stated. Organic solvents and $\mathrm{N}$ bromosuccinimide, sym-collidine, mercaptopropionic acid, methylReceived 3 July 1992. morpholine, isobutyl chloroformate, maleic anhydride, succinic anhydride and triethalonamine were purchased from Merck (Darmstadt), BSA and Freund's adjuvants from Sigma (St Louis, $\mathrm{MO}$ ), horseradish peroxidase (HRP) from Boehringer Mannheim (Mannheim) and microtitre plates from Nunc (Kamstrup). The immunogens $11 \alpha$-hydroxyhemisuccinate-progesterone-BSA and $6 \beta$-hydroxy-hemisuccinate-progesterone-BSA were obtained from Steraloids, 3-O-carboxymethyl oxime-progesterone-BSA from Sigma and $7 \alpha$-carboxyethyl thioether-progesterone-BSA was synthesized (Grover and Odell, 1977; van de Wiel and Koops, 1986).

\section{Antibodies}

Antiserum was raised in rabbits against the four immunogens and the immunoglobulin fractions were purified with caprylic acid (Hatzidakis et al., 1990).

\section{Conjugates}

3-O-carboxymethyl oxime-progesterone, $11 \alpha$-hydroxyhemisuccinate-progesterone, 11 $\alpha$-hydroxyhemimaleate-progesterone, $6 \beta$-hydroxyhemimaleate-progesterone, $6 \beta$-hydroxyhemisuccinate-progesterone and $7 \alpha$-carboxyethyl thioetherprogesterone were conjugated to HRP using the mixed anhydride method (Liebermann et al., 1959). The hormone : HRP ratios were $1: 1$.

\section{Enzymeimmunoassay procedure}

Briefly, flat-bottomed microtitration plates (Maxisorb, Nunc) were coated $100 \mu \mathrm{l}$ per well $\left(1 \mu \mathrm{g} \mathrm{ml}^{-1}\right)$ with the appropriate antiprogesterone purified immunoglobulin in carbonate-bicarbonate buffer $\left(50 \mathrm{mmol} \mathrm{I}^{-1} ; \mathrm{pH} 9.6\right)$, overnight at $4^{\circ} \mathrm{C}$. Excess antibody 
Table 1. Assay sensitivities
Antibody
Conjugate
Sensitivity (pg)

3-O-carboxymethyl oxime-progesterone-BSA

I1 $\alpha$-hemisuccinate-progesterone-BSA

$6 \beta$-hemisuccinate-progesterone-BSA

$7 a$-carboxyethyl thioether-progesterone-BSA
3-O-carboxymethyloxime-progesterone

$6 \beta$-hemisuccinate-progesterone

$11 \alpha$-hemisuccinate-progesterone

$11 \alpha$-hemimaleate-progesterone

3-O-carboxymethyl oxime-progesterone

$6 \beta$-hemisuccinate-progesterone

$6 \beta$-hemimaleate-progesterone

3-O-carboxymethyl oxime-progesterone

$7 \alpha$-carboxyethyl thioether-progesterone

$7 \alpha$-carboxyethyl thioether-progesterone

$6 \beta$-hemimaleate-progesterone

$6 \beta$-hemisuccinate-progesterone
400

200

400

150

150

120

50

50

50

30

12

12

aDose for $50 \%$ inhibition of tracer binding.

was washed off with distilled water containing $0.05 \%$ Tween 20 (Merck, Darmstadt) and the coated wells were blocked with $200 \mu \mathrm{l}$ per well of $1 \% \mathrm{w} / \mathrm{v}$ BSA in saline for $1 \mathrm{~h}$ at room temperature. Test samples (serum or milk), $10 \mu \mathrm{l}$, or solutions with standard concentrations of progesterone were added to wells in duplicate, plus $200 \mu \mathrm{l}$ of hapten-peroxidase conjugate at $1 / 50000$. The mixture was incubated at room temperature for $I \mathrm{~h}$. After three washes with distilled water, the antibodyantigen reaction was revealed by adding $100 \mu \mathrm{l}$ of substrate $\left(0.25 \mathrm{~mol} 3,3^{\prime}, 5,5^{\prime}\right.$ tetramethylbenzidine $\mathrm{l}^{-1}, 0.03 \% \mathrm{v} / \mathrm{v}$ hydrogen peroxidase in sodium acetate buffer $\left(50 \mathrm{mmol} \mathrm{l}^{-1} ; \mathrm{pH} 5.2\right)$ to each well. The reaction was stopped after $15 \mathrm{~min}$ by the addition of $50 \mu \mathrm{l}$ sulfuric acid $\left(2 \mathrm{~mol} \mathrm{l}^{-1}\right)$ per well. The absorbance was measured at $450 \mathrm{~nm}$ (Multiskan, Flow, Finland).

\section{Results}

\section{Comparison of different antibody-conjugate assay systems}

All homologous assays gave lower sensitivities (Abraham, 1969) than the corresponding heterologous systems (Table 1). Two of the most sensitive antibody-conjugate systems were assessed for specificity by measuring crossreactivity with a number of relevant commercially available steroids (Steraloids, Wilton) (Table 2). The best sensitivity and specificity were obtained with the combination of $7 \alpha$-carboxyethyl thioetherprogesterone antibodies with $6 \beta$-hemisuccinate-progesterone (or the hemimaleate version) as conjugate. This combination was further assessed as an assay for measuring progesterone in human sera and bovine milk.

\section{Assay characteristics in human sera and bovine milk}

Progesterone standards in human serum were prepared by adding appropriate amounts of hormone from a stock solution ( $45 \mu \mathrm{g} \mathrm{ml}^{-1}$ in ethanol, $E_{240}=171 \mathrm{mmol} \mathrm{l}^{-1}$ ) to a selected serum with no detectable progesterone. Eight standards were made which covered the intended range $(0-100$ ng progesterone $\mathrm{ml}^{-1}$ serum). Reproducibility of the calibration curve was tested by repeat measurements of these standards (Table 3 ). Similar results were observed with four standards $(0,5,10$ and $20 \mathrm{ng}$ progesterone $\mathrm{ml}^{-1}$ ) prepared in bovine whole milk which was taken from cows 8-10 days after giving birth and which contained no detectable progesterone. The range of the milk standards was selected to be sufficient in the discrimination between pregnant and nonpregnant animals.

The sensitivity of the serum assay, calculated as the concentration of progesterone detected at three standard deviations from the zero standard, was $0.25 \mathrm{ng} \mathrm{ml}^{-1}$. The sensitivity of the milk assay was not determined as concentrations below $1 \mathrm{ng} \mathrm{ml}{ }^{-1}$ were considered not to be of diagnostic use.

Precision was tested by replicate measurement of two human serum samples, one with low and one with high progesterone concentrations. The intra-assay mean value for the first sample was $1.30 \mathrm{ng} \mathrm{ml}^{-1}$ ( $n=64$, coefficient of variation, $\mathrm{CV}=3.0 \%$ ) and for the second sample $15 \mathrm{ng} \mathrm{ml}^{-1}(n=56, \mathrm{CV}=5.9 \%$ ), whereas the interassay values (different batches of reagents) were $1.27 \mathrm{ng} \mathrm{ml}^{-1}(n=4, \mathrm{CV}=3.4 \%)$ and $14 \mathrm{ng} \mathrm{ml}^{-1}(n=4$, $\mathrm{CV}=9.8 \%$, respectively. Similar tests with two bovine whole milk samples gave intra-assay values of $2.4 \mathrm{ng} \mathrm{ml}^{-1}(n=50$, $\mathrm{CV}=5.3 \%)$ and $50 \mathrm{ng} \mathrm{ml}^{-1}(n=34, \mathrm{CV}=4.0 \%)$, and interassay values of $2.4 \mathrm{ng} \mathrm{ml}^{-1}\left(n=6, \mathrm{CV}=5.0 \%\right.$ and $4.9 \mathrm{ng} \mathrm{ml}^{-1}$ ( $n=4, \mathrm{CV}=9.1 \%$ ), respectively.

Accuracy of the readings was tested by comparing values obtained from the assay with those determined by a commercially available RIA (Amerlex, Amersham) in 103 samples of human sera. The correlation coefficient between the two assays was $r=0.915$. Accuracy of measurement was further tested by determining recovery by adding 1.0, 5.0 and $15 \mathrm{ng}$ progesterone $\mathrm{ml}^{-1}$ to two human sera with native progesterone concentrations of 1.8 and $28 \mathrm{ng} \mathrm{ml}^{-1}$ respectively, and a bovine milk sample with $2.4 \mathrm{ng} \mathrm{ml}^{-1}$ (Table 4). 
Table 2. Assay specificity

\begin{tabular}{|c|c|c|}
\hline \multirow[b]{2}{*}{ Steroid } & \multicolumn{2}{|c|}{$\%$ Crossreactivity } \\
\hline & $\begin{array}{c}6 \beta \text {-hs-prog and } \\
6 \beta \text {-hm-prog }\end{array}$ & $\begin{array}{l}7 \alpha \text {-ct-prog- } \\
6 \beta \text {-hs-prog }\end{array}$ \\
\hline Progesterone & 100.0 & 100.0 \\
\hline $11 \alpha$-Hydroxyprogesterone & 3.3 & 1.0 \\
\hline $5 \alpha$-Pregnane-3,20-dione & 33.0 & 2.8 \\
\hline $5 \beta$-Pregnane-3,20-dione & 1.2 & 10.0 \\
\hline $3 \alpha$-Hydroxy-5 $\beta$-pregnane-20-one & Not tested & 1.8 \\
\hline $3 \beta$-Hydroxy-5 $\beta$-pregnane-20-one & 4.2 & 4.0 \\
\hline 21-Hydroxy-4-pregnene-3,20-dione & $<0.1$ & 1.2 \\
\hline 21-Hydroxy-4-pregnene-3,20-dione acetate & 0.3 & $<0.1$ \\
\hline 17-Hydroxy-4-pregnene-3,20-dione & 1.5 & $<0.1$ \\
\hline Oestriol & $<0.1$ & $<0.1$ \\
\hline Oestrone & 0.2 & $<0.1$ \\
\hline Oestradiol & $<0.1$ & $<0.1$ \\
\hline Corticosterone & 0.3 & $<0.1$ \\
\hline Cortisol & $<0.1$ & $<0.1$ \\
\hline 4-Androstene-3,17-dione & $<0.1$ & $<0.1$ \\
\hline $3 \beta$-Hydroxy-5-androsten- 17 one & $<0.1$ & $<0.1$ \\
\hline Testosterone & $<0.1$ & $<0.1$ \\
\hline
\end{tabular}

${ }^{a}$ Crossreactivity was defined as the amount of steroid (pg), relative to progesterone, required to reduce label binding by $50 \%$.

${ }^{b}$ Antibody, $6 \beta$-hemisuccinate-progesterone and conjugate, $6 \beta$-hemimaleate-progesterone.

'Antibody, $7 \alpha$-carboxyethyl thioether-progesterone and conjugate, $6 \beta$-hemisuccinate-progesterone.

Table 3. Reproducibility of the calibration curve for progesterone in human serum

\begin{tabular}{|c|c|c|c|c|c|}
\hline \multirow[b]{2}{*}{$\begin{array}{l}\text { Reference } \\
\text { standard }\end{array}$} & \multirow[b]{2}{*}{$\begin{array}{l}\text { Progesterone } \\
\quad\left(\mathrm{ng} \mathrm{ml} \mathrm{ml}^{-1}\right)\end{array}$} & \multicolumn{2}{|c|}{ Intra-assay values ${ }^{\mathrm{a}}$} & \multicolumn{2}{|c|}{ Interassay values $^{b}$} \\
\hline & & $\begin{array}{c}\text { Mean } \\
\text { absorbance } \\
\text { (450 nm) }\end{array}$ & $\mathrm{CV} \%$ & $\begin{array}{c}\text { Mean } \\
\text { absorbance } \\
(450 \mathrm{~nm})\end{array}$ & $\mathrm{CV} \%$ \\
\hline 1 & 0.0 & 1.090 & 4.6 & 1.063 & 2.5 \\
\hline 2 & 0.4 & 0.900 & 3.1 & 0.890 & 3.5 \\
\hline 3 & 1.0 & 0.650 & 4.0 & 0.645 & 3.2 \\
\hline 4 & 2.5 & 0.500 & 3.1 & 0.490 & 3.9 \\
\hline 5 & 5.0 & 0.390 & 3.2 & 0.390 & 3.9 \\
\hline 6 & 10.0 & 0.290 & 4.7 & 0.280 & 4.0 \\
\hline 7 & 30.0 & 0.170 & 5.1 & 0.165 & 5.5 \\
\hline 8 & 100.0 & 0.110 & 7.9 & 0.100 & 5.2 \\
\hline
\end{tabular}

'The results were obtained from 12 replicates.

${ }^{b} T$ The results were obtained from four different batches of reagents, tested on four different occasions. $\mathrm{CV}$ : Coefficient of variation.

Application of the assay for early pregnancy diagnosis in dairy cattle

The assay was evaluated as a cattle pregnancy diagnostic tool. Pregnancy testing was performed on 49 cows by taking milk samples on the day of insemination and 19 days later. Accuracy of positive and negative diagnoses was assessed with data from oestrous returns or subsequent calving (Table 5).

\section{Discussion}

This is the first report on the influence of different chemically modified progesterone conjugates and antibodies to an EIA, thus allowing a more rational design of a progesterone assay. Antibodies directed to $7 \alpha$-carboxyethyl thioether-progesterone gave the greatest competitive inhibition in contrast to antibodies against 3-O-carboxymethyl-oxime-progesterone and 
Table 4. Recovery of progesterone-added samples

\begin{tabular}{|c|c|c|c|c|c|}
\hline $\begin{array}{l}\text { Type of } \\
\text { sample }\end{array}$ & $\begin{array}{c}\text { Basal } \\
\text { progesterone } \\
\left(\mathrm{ng} \mathrm{ml} \mathrm{ml}^{-1}\right)\end{array}$ & $\begin{array}{c}\text { Progesterone } \\
\text { added } \\
\left(\mathrm{ng} \mathrm{m} \mathbf{m}^{-1} \text { ) }\right.\end{array}$ & $\begin{array}{l}\text { Observed } \\
\text { value } \\
\left(\mathrm{ng} \mathrm{ml}^{-1}\right)\end{array}$ & $\%$ Recovery I & \% Recovery II \\
\hline \multirow{3}{*}{ Human serum } & 1.8 & 1.0 & 3.0 & 120 & 107 \\
\hline & & 5.0 & 7.0 & 104 & 103 \\
\hline & & 15.0 & 17.0 & 101 & 101 \\
\hline \multirow[t]{3}{*}{ Human serum } & 28.0 & 1.0 & 30.0 & - & 103 \\
\hline & & 5.0 & 34.0 & 120 & 103 \\
\hline & & 15.0 & 42.0 & 93 & 98 \\
\hline \multirow[t]{3}{*}{ Bovine milk } & 2.4 & 1.0 & 3.5 & 110 & 103 \\
\hline & & 5.0 & 7.0 & 92 & 95 \\
\hline & & 15.0 & 17.0 & 97 & 98 \\
\hline
\end{tabular}

$\%$ recovery I: (increment found $/$ increment added) $\times 100 ; \%$ recovery II: $\{$ (observed value $) /($ basal value + increment added) $\} \times 100$.

Table 5. Pregnancy diagnosis with bovine milk

\begin{tabular}{|c|c|c|c|c|c|}
\hline & Inseminated & $\begin{array}{c}\text { Positive test }^{\mathrm{a}} \\
\text { on day } 19\end{array}$ & Calved & $\begin{array}{c}\text { Negative test } \\
\text { on day } 19\end{array}$ & $\begin{array}{c}\text { Return to } \\
\text { oestrus }\end{array}$ \\
\hline $\begin{array}{l}\text { Number of animals } \\
\text { Mean progesterone concentration } \\
\text { (ng ml-1) (range) }\end{array}$ & $\begin{array}{c}49 \\
1.45(1<\text { to } 5)\end{array}$ & $\begin{array}{c}39 \\
22.8(10-58)\end{array}$ & $33(84.6 \%)^{b}$ & $1.92(1<$ to 5$)$ & $10(100 \%)$ \\
\hline
\end{tabular}

aPositive: Progesterone $\geq 10 \mathrm{ng} \mathrm{ml}^{-1}$; baccuracy based on calving rate.

$11 \alpha$-hemisuccinate-progesterone which gave poor inhibition. In all situations, assays with heterologous conjugates were at least twice as sensitive as with the corresponding homologous conjugates. Previous studies regarding homologous EIAs reported just adequate sensitivity (Joyce et al., 1977; Sauer et al., 1981; Foulkes et al., 1982).

The use of heterologous progesterone conjugates with antibodies increased sensitivity considerably. The improvement was approximately the same for any given antibody, irrespective of the type or position of the bridge in the conjugate. Our results suggest that the overall sensitivity of a heterologous system is governed by the antibody rather than by the conjugate. This appears to be the case here and in other studies that describe heterologous progesterone EIAs (Munro and Stabenfeldt, 1984; Marcus and Hackett, 1986; Sauer et al., 1986; van de Wiel and Koops, 1986). In our study the best combination was the $7 \alpha$-carboxyethyl-thioether-progesterone/ $6 \beta$-hemisuccinateprogesterone system, which is similar to the system described by van de Wiel and Koops (1986).

Specificity is a well-recognized problem with progesterone assays (Grover and Odell, 1977). The heterologous EIA tests crossreact strongly with three related steroids: with $11 \alpha$ hydroxyprogesterone, 95\% (Marcus and Hackett, 1986), 75.8\% (Sauer ef al., 1986), 21.4\% (Munro and Stabenfeldt, 1984) and $5.6 \%$ (van de Wiel and Koops, 1986); with $5 \alpha$-pregnane-3,20dione, 50\% (Marcus and Hackett, 1986), 29.5\% (Munro and
Stabenfeldt, 1984) and 25.0\% (van de Wiel and Koops, 1986); and with $5 \beta$-pregnane-3,20-dione, 48\% (Marcus and Hackett, 1986) and $6.8 \%$ (Sauer et al., 1986). The corresponding crossreactivity of our $7 \boldsymbol{\alpha}$-carboxyethyl-thioether-progesterone and $6 \beta$-hemisuccinate-progesterone assay was $1.0 \%, 2.8 \%$ and $10.0 \%$, respectively, which represents a considerable improvement in specificity. Although our assay and that described by van de Wiel and Koops (1986) are essentially similar, the differences in sensitivity may be attributed to the different starting materials.

The assay is simple and convenient to use, as it permits direct addition of undiluted sample and conjugate, and requires a short incubation period. The good sensitivity of the assay is reflected by the volume of the sample used ( $10 \mu \mathrm{l}$ per test) and by the displacement of the conjugate at low concentrations (17.5\% displacement by $0.4 \mathrm{ng}$ progesterone $\left.\mathrm{ml}^{-1}\right)$, with at least comparable performance to commercially available reagents.

The diagnostic results with the bovine milk agree with results obtained in previous studies using RIA (Robertson $e t$ al., 1971) and EIA (Sauer et al., 1986; van de Wiel et al., 1986). As the test requires less than 90 min to complete, a major application in cattle could be centralized testing of large numbers of samples, thus allowing close supervision by trained veterinarians for the correct interpretation of the results which could improve the overall management of cows. 
We would like to thank M. Papadopoulos of the University of Crete for his invaluable advice on the preparation of the immunogens and $\mathrm{K}$. Katrakili for her assistance in the synthesis of the hormone derivatives.

\section{References}

Abraham GE (1969) Solid-phase radioimmunoassay of estradiol-17 $\beta$ journal of Clinical Endocrinology and Metabolism 29 866-870

Foulkes JA, Cookson AD and Sauer MJ (1982) AI in cattle based on daily microtitre plate enzyme-immunoassay of progesterone in whole milk British Veterinary Joumal 138 515-521

Hatzidakis G, Katrakili K and Krambovitis E (1990) Development of an ELISA test for the determination of progesterone and oestrone sulphate Proceedings of the 5th Hellenic Veterinary Congress, November 1990, Salonika, Greece pp 13-14. Greek Veterinary Society

Heap RB, Gwyn M, Laing JA and Walters DE (1973) Pregnancy diagnosis in cows: changes in milk progesterone concentration during the oestrous cycle and pregnancy measured by a rapid radioimmunoassay joumal of Agricultural Sciences 81 151-157

Hoffmann B and Hamburger R (1973) Progesteron in der Milch: radioimmunolgische bestimmung, begiehungen zur Gelbkorperfunktion und Milchfettkonzentration Zuchthygiene 8 154-162
Grover PK and Odell WD (1977) Specificity of antisera to sex steroids I. The effect of substitution and stereochemistry Journal of Steroid Biochemistry 8 121-126

Joyce BG, Read GF and Fahmy DR (1977) A specific enzymeimmunoassay for progesterone Steroids 29 761-770

Liebermann S, Erlanger BF, Beiser SM and Agate FJ (1959) Steroid-protein conjugates: their chemical, immunological and endocrinological properties Progress of Hormone Research 15 165-169

Marcus GJ and Hackett AJ (1986) Use of enzyme-linked immunosorbent assay for measurement of bovine serum and milk progesterone without extraction Joumal of Dairy Science 69 818-824

Munro $C$ and Stabenfeldt G (1984) Development of a microtitre plate enzyme immunoassay for the determination of progesterone Joumal of Endocrinology $10141-49$

Robertson HA and Sarda IR (1971) A very early pregnancy test for mammals: its application to the cow, ewe and sow Joumal of Endocrinology 49 407-719

Sauer MJ, Foulkes JA and Cookson AD (1981) Direct enzymeimmunoassay of progesterone in bovine milk Steroids 38 45-53

Sauer MJ, Foulkes JA, Worsford A and Morris BA (1986) Use of progesterone 11-glucuronide-alkaline phosphatase conjugate in a sensitive microtitreplate enzymeimmunoassay of progesterone in milk and its application to pregnancy testing in dairy cattle Journal of Reproduction and Fertility 76 $375-391$

Van de Wiel DFM and Koops W (1986) Development and validation of an enzyme immunoassay for progesterone in bovine milk or blood plasma Animal Reproduction Science 10 201-213 